\title{
Çinko Uygulamasının Kanola (Brassica napus ssp. oleifera L.) Çeșitlerinin Verim ve Sabit Yağ Oranı Üzerine Etkisi
}

\author{
Zehra AYTAÇ*1 Nurdilek GÜLMEZOĞLU² İmren KUTLU³ İnci TOLAY \\ 'Eskișehir Osmangazi Üniversitesi Ziraat Fakültesi, Tarla Bitkileri Bölümü, Eskișehir \\ ${ }^{2}$ Eskișehir Osmangazi Üniversitesi Ziraat Fakültesi Toprak Bilimi ve Bitki Besleme Bölümü, Eskișehir \\ ${ }^{3}$ Eskișehir Osmangazi Üniversitesi Ziraat Fakültesi, Eskișehir \\ ${ }^{4}$ Akdeniz Üniversitesi Ziraat Fakültesi Toprak Bilimi ve Bitki Besleme Bölümü, Antalya
}

\begin{abstract}
*Sorumlu yazar e-posta (Corresponding author e-mail) : zehrak@ogu.edu.tr
Geliș tarihi (Received) : 26.03.2016

Kabul tarihi (Accepted): 21.04 .2016
\end{abstract}

\section{Öz}

Bu araștırma, topraktan çinko (Zn) uygulamasının, iki kıșlık kanola (Brassica napus ssp. oleifera L.) çeșidinin (Samuray ve Zorro) verim ve sabit yağ oranı üzerine etkisini belirlemek amacıyla iki yetiștirme yılında yürütülmüștür. Deneme, tesadüf blokları deneme desenine göre dört tekrarlamalı olarak kurulmuștur. Ekim öncesinde $3 \mathrm{~kg} \mathrm{da}^{-1} \mathrm{Zn}$ çinko sülfat $\left(\mathrm{ZnSO}_{4} \cdot 7 \mathrm{H}_{2} \mathrm{O}\right)$ șeklinde $\mathrm{Zn}$ gübrelemesi yapılmıștır. Bitki boyu, yan dal sayısı, bitkide kapsül sayısı, kapsül uzunluğu, kapsülde tane sayısı, tohum verimi ve yağ oranı gibi özelliklerin incelendiği araștırma sonuçlarına göre; Zn uygulaması tohum verimini artıs yönünde önemli düzeyde etkilemiștir. Yağ oranında istatistiki olarak önemli düzeyde olmayan bir artıș eğilimi tespit edilmiștir. Çeșitler ise bitki boyu, yan dal sayısı ve bin tane ağırlığı özellikleri bakımından varyasyon göstermiștir. Çeșitler Zn uygulamalarından farklı etkilenmiștir. Çinko uygulamasına tohum verimi artıșı bakımından en iyi cevap veren çeșit Samuray çeșidi olmuș, veriler yıllara göre değișiklik göstermiștir.

Anahtar Kelimeler: Çinko, gübreleme, kanola, verim, yağ oranı.

\section{The Effect of Zinc Application on Yield and Oil Content of Rapeseed (Brassica napus ssp. oleifera L.) Cultivars}

\begin{abstract}
This research was carried out to determine the effect of zinc $(Z n)$ application by soil on yield and seed oil content of two winter canola (Brassica napus ssp. oleifera L.) cultivars (cv. Samourai and cv. Zorro) in two experimental years. The experimental design of the study was a randomized complete block with four replications. $3 \mathrm{~kg} \mathrm{da}{ }^{-1}$ Zinc was applied as zinc sulphate $\left(\mathrm{ZnSO}_{4} \cdot 7 \mathrm{H}_{2} \mathrm{O}\right)$ fertilizer to the soil before sowing. According to the results of the study examined in traits such as plant height, number of lateral branches, number of capsule per plant, capsule length, number of seed per capsule, seed yield and seed oil content; seed yield was affected to be increased significantly, oil percent showed a tendency to be increased at insignificant level statistically by the Zn application. Cultivars showed variations in plant height, the number of lateral branches and thousand seed weight. Cultivars were affected differently by the zinc application. Samourai has the best response to Zn application for increase in seed yield, and the data varied according to years.
\end{abstract}

Key Words: Zinc, fertilization, canola, yield, oil content. 


\section{Giriș}

Kanola (Brassica napus ssp. oleifera L.), dünya yağ bitkileri üretiminde önemli bir yere sahip olan ve ülkemizde de yağlı tohum üretimindeki boșluğu kapatabilecek önemli bir bitkidir. Genellikle Avrupa, Asya, Kuzey Amerika, Avustralya ve Çin'de üretimi yapılan kanolanın dünyadaki ekim alanı 36,4 milyon hektar ve üretimi ise 71 milyon ton civarındadır. Ülkemizdeki üretim alanı 32,7 bin hektar ve üretim miktarı 110 bin tondur (Anonim, 2014). Kanola ekimine yapılan desteklemelerin ülkemizde daha önce kısıtlı olan tarımının yaygınlașmasını sağlaması bakımından önemi büyük olmuștur.

Tohumunda ortalama \% 38-50 yağ, \% 16-24 protein, \% 20 polisakkaritler polisakkaritler içeren ve oldukça yüksek kalitede yağ asitleri kompozisyonuna sahip olan (oleik asit: \% 59,8; linoleik asit: \% 19,4) bitki (Downey ve Röbbelen, 1989), yemeklik yağ elde edilmesinin dıșında; sabun sanayinde, boya ve vernik yapımında, derileri yumușatmada, süetlere elastikiyet vermede, tıpta, sentetik madde yapımında, emulgatör eldesinde, hidrolik yağı ve biyodizel üretiminde kullanılmaktadır (Tan, 2009).

Kanola yazlık ve kıșlık çeșitleri olan bir yağ bitkisidir. Yetișme devresi kısadır. Illkbaharda hızlı gelișerek yabancı otların gelișmesini engellemesi ile kendisinden sonraki ürüne temiz toprak bırakmaktadır. Ayrıca hasat zamanının diğer yağ bitkilerinden 1-2 ay erken olması sebebiylede, hem yağ fabrikalarına hammadde sağlayarak çalıșma kapasitesini yükseltmesi, hem de uygun bölgelerde ikinci ürün tarımına imkan sağlaması gibi üstün özellikleri bulunmaktadır (Kırıcı ve Özgüven, 1995). Ayrıca, birim alandan yüksek tohum verimi elde edilmesi, yağ oranının yüksek olması (\% 40-48), toprak isteklerinin az olması, ekiminden hasadına kadar tarımının mekanizasyona uygun olması gibi özellikleri de kanola tarımını özendirecek diğer özelliklerdir (Kolsarıcı vd., 2005). Orta Anadolu Bölgesi'nde yapılan çeșitli çalıșmalardan elde edilen sonuçlar, kıșlık olarak yetiștirilen bazı kanola çeșitlerinden ekonomik düzeyde yüksek tohum veriminin alınabileceğini göstermektedir. Kıșlık ekiminden hemen sonra sonbahar yağıșlarının yetersiz olduğu yörelerde tek bir çıkıș sulaması yapılarak ekim nöbetine rahatlıkla girebilecek yağ bitkilerinin bașında yer almaktadır. (Öğütcü, 1979; Kolsarıcı vd., 1985; Bașalma ve Kolsarıcı, 1998; Öztürk ve Akınerdem, 2000; Bașalma, 2004; Aytaç ve Kınacı, 2007).
Ülkemizin yağ açığı dikkate alındığında, kanola bölge için önemli alternatif bir bitki olmakta, üretiminin geliștirilmesi ve yaygınlaștırıması açısından uygun yetiștirme tekniklerinin ve gübreleme uygulamalarının belirlenmesi önem tașımaktadır. Azot ve fosfor gibi makro besin elementlerinin yanı sıra mikro besin elementleri de bitki yetiștirmede önemli bir yere sahiptir.

Çinko (Zn) eksikliği dünyada ve Türkiye'de yaygın olarak rastlanan bir mikro besin elementi problemidir. Bitkiye yarayıșlı çinko miktarının, dünyada ve Türkiye'de tarım yapılan toprakların yakklașık olarak \% 50'sinde düșük olduğu belirlenmiștir. Orta Anadolu bölgesinde ise bu oran \% 80 civarındadır (Çakmak vd., 1996). Topraktaki toplam miktarının düșük olmasının yanı sıra yüksek organik madde içeriği, yüksek fosfat durumu, yüksek tuzluluk gibi faktörler de bitkilerin Zn alımını etkilemektedir (Alloway, 2008). Bu durumun bir sonucu olarak; bitkilerde, verim ve kalite azalırken, insanlarda da çok yaygın bir biçimde Zn noksanlığı görülmekte ve beslenmedeki Zn yetersizliği sağlık problemlerine yol açmaktadır (Çakmak vd., 1999; Nriagu, 2010).

Zn eksikliği olan bölgelerde, topraktan veya yapraktan yapılacak Zn'lu gübre uygulamaları ile bu eksiklik giderilebilir. Dünyada kanola bitkisinin Zn eksikliği görülen topraklarda yetiștirilmesi ve Zn uygulamalarının verim ve kalite üzerindeki etkileri ile ilgili bazı çalıșmalar olup (Hu vd., 1994; Grewal vd., 1997; Huang vd., 1995; Grewal vd., 1997 a,b), özellikle ülkemizde ve dünyada tarla koșullarındaki etkileri hakkında yeterli araștırma bulunmamaktadır. Bu çalıșmada topraktan Zn uygulamasının, iki kıșlık kanola çeșidinin verim, verim özelikleri ve sabit yağ oranına etkisini belirlemek amaçlanmıștır.

\section{MATERYAL VE YÖNTEM}

Araștırma, Eskișehir Osmangazi Üniversitesi Ziraat Fakültesi deneme tarlasında 2004/05 ve 2006/07 yıllarında yürütülmüștür. Deneme yerine ait iklim özellikleri Çizelge 1'de gösterilmiștir. Bitkilerin yetișme süresince düșen toplam yağıș miktarı, ortalama sıcaklık ve ortalama nispi nem sırasıyla, ilk yıl için $336,5 \mathrm{~mm}, 10,11^{\circ} \mathrm{C}$ ve \% 60, 19; ikinci yll için 393,7 mm, 9,93ㅇ $\mathrm{C}$ ve 60,50; uzun yıllar toplamı $363,5 \mathrm{~mm}$, uzun yıllar ortalaması $9,85^{\circ} \mathrm{C}$ ve \% 68 olmuștur (Anonim, 2007). 
Çizelge 1. Eskișehir ili koșullarına ait iklim verileri

Table 1. Meteorological data of Eskisehir province

\begin{tabular}{|c|c|c|c|c|c|c|c|c|c|}
\hline \multirow[b]{2}{*}{ Aylar } & \multicolumn{3}{|c|}{ Uzun Yıllar* } & \multicolumn{3}{|c|}{$2004-2005$} & \multicolumn{3}{|c|}{$2006-2007$} \\
\hline & $\begin{array}{c}\text { Toplam } \\
\text { Yağıș } \\
\text { (mm) }\end{array}$ & $\begin{array}{c}\text { Ortalama } \\
\text { Sicaklık } \\
\left({ }^{0} \mathrm{C}\right)\end{array}$ & $\begin{array}{c}\text { Ortalama } \\
\text { Nem } \\
(\%)\end{array}$ & $\begin{array}{c}\text { Toplam } \\
\text { Yağıș } \\
\text { (mm) }\end{array}$ & $\begin{array}{c}\text { Ortalama } \\
\text { Sicaklık } \\
\left({ }^{0} \mathrm{C}\right)\end{array}$ & $\begin{array}{c}\text { Ortalama } \\
\text { Nem } \\
(\%)\end{array}$ & $\begin{array}{l}\text { Toplam } \\
\text { Yağıș } \\
\text { (mm) }\end{array}$ & $\begin{array}{c}\text { Ortalama } \\
\text { Sicaklık } \\
\left({ }^{0} \mathrm{C}\right)\end{array}$ & $\begin{array}{c}\text { Ortalama } \\
\text { Nem } \\
(\%)\end{array}$ \\
\hline Eylül & 16,6 & 16,9 & 60,0 & 0,0 & 17,5 & 48,9 & 93,0 & 16,6 & 58,9 \\
\hline Ekim & 25,6 & 11,9 & 66,0 & 5,8 & 12,8 & 59,4 & 47,5 & 12,6 & 71,1 \\
\hline Kasım & 30,5 & 6,6 & 74,0 & 15,1 & 5,7 & 67,9 & 16,8 & 3,9 & 68,5 \\
\hline Aralık & 48,1 & 2,0 & 80,0 & 26,2 & 1,4 & 75,8 & 6,8 & $-0,7$ & 70,1 \\
\hline Ocak & 39,9 & $-0,2$ & 80,0 & 19,4 & 2,1 & 74,3 & 42,2 & 0,0 & 74,1 \\
\hline Șubat & 33,9 & 1,2 & 77,0 & 47,5 & 1,5 & 65,9 & 14,2 & 1,5 & 68,1 \\
\hline Mart & 36,6 & 4,6 & 70,0 & 48,3 & 4,9 & 62,0 & 24,0 & 5,4 & 63,0 \\
\hline Nisan & 39,2 & 10,1 & 64,0 & 38,3 & 10,0 & 52,6 & 25,0 & 7,5 & 54,7 \\
\hline Mayıs & 46,2 & 15 & 63,0 & 53,6 & 14,7 & 56,6 & 65,6 & 17,8 & 49,1 \\
\hline Haziran & 33,5 & 18,7 & 60,0 & 33,8 & 18,2 & 50,3 & 58,6 & 20,8 & 47,9 \\
\hline Temmuz & 13,4 & 21,5 & 54,0 & 48,5 & 22,4 & 48,4 & - & 23,8 & 40,0 \\
\hline Toplam & 363,5 & & & 336,5 & & & 393,7 & & \\
\hline Ortalama & & 9,85 & 68,00 & & 10,11 & 60,19 & & 9,93 & 60,50 \\
\hline
\end{tabular}

*Uzun Yıllar (1945-2005) ortalama iklim verileri

Deneme alanına ait toprak analiz sonuçları Çizelge 2' de verilmiștir. Araștırma alanının toprak örneklerinde $\mathrm{pH}$ (toprak:su: 1:2) (Richards, 1954), toplam tuz (Richards, 1954), bünye (Bouyoucos, 1955), organik madde (Walkley ve Black (1934), toplam fosfor (Olsen ve Dean, 1965), potasyum (Caarson, 1980), demir, çinko, mangan, bakır (Lindsay ve Norvell, 1978) analizleri yapılmıștır.

Araștırma alanının toprakları hafif alkalin, tuzsuz ve killi tınlı, organik madde çok düșük, orta kireçli, alınabilir fosfor az, potasyum yeterli, çinko az, demir orta, mangan az ve bakır yeterli seviyede olarak belirlenmiștir.

Araștırmada materyal olarak, Samuray ve Zorro kıșlık kanola çeșitleri kullanılmıștır. İki faktörün (uygulama; çinkolu ve çinkosuz, çeșit; Samuray ve Zorro) incelendiği araștırmanın tarla denemeleri, tesadüf blokları deneme deseninde faktöriyel düzende $3 \mathrm{~m}$ uzunluğundaki parsellerde 4 tekrarlamalı olarak kurulmuștur. Araștırmada, Samuray ve Zorro kıșlık kanola çeșitleri $2 \times 3=6 \mathrm{~m}^{2}$ büyüklüğündeki parsellere $40 \mathrm{~cm}$ sıra aralığılla tesadüf blokları deneme deseninde, faktöriyel düzende 4 tekrarlamalı olarak, $1 \mathrm{~kg} \mathrm{da-1}$ tohum olacak șekilde Eylül ayının ilk haftasında ekim yapılmıștır ve can suyu verilmiștir. Vejetasyon süresi boyunca bașka sulama uygulaması yapıImamıștır. Tüm parsellere temel gübrelemede ekimle birlikte 5 $\mathrm{kg} \mathrm{da} \mathrm{P}^{-1} \mathrm{P}_{2} \mathrm{O}_{5}$ içerecek diamonyum fosfat $(\% 18 \mathrm{~N}$, $\left.\% 46 \quad \mathrm{P}_{2} \mathrm{O}_{5}\right)$ gübresi uygulanmıștır. Dekara uygulanacak toplam $15 \mathrm{~kg} \mathrm{da}^{-1} \mathrm{~N}$ 'un yarısı ekimde amonyum sülfat gübresi $\left(\begin{array}{llll}\% & 20.5 & \mathrm{~N}\end{array}\right)$ ile tamamlanarak kalanı ise bitkilerin sapa kalkma döneminde amonyum nitrat (\% $33 \mathrm{~N}$ ) gübresi olarak Kolsarıcı (2009) ve Bașalma (1999)' nın bildirdiği șekilde uygulanmıștır. Kontrol parsellerine yalnızca temel gübreleme yapılmıș, uygulama parsellerine ise ekim öncesinde $3 \mathrm{~kg} \mathrm{da}^{-1} \mathrm{Zn}$, çinko sülfat $\left(\mathrm{ZnSO}_{4} \cdot 7 \mathrm{H}_{2} \mathrm{O}\right)$ uygulanmıștır.

Yabancı ot mücadelesi sonbaharda çıkıș sonrasında çapa ile yapılmıștır. Hasat, Haziran ayının son haftasında el ile budama makası yardımıyla gerçekleștirilmiștir. Bitki boyu, yan dal sayısı, bitkide kapsül sayısı, kapsül uzunluğu, kapsülde tohum sayısı, bin tane ağırlığı ve tohum verimleri incelenmiștir. İlk yıl çinko uygulamasının tohumdaki sabit yağ oranının etkisi de belirlenmiștir. Yağ oranları Gerhard 2000 marka dijital sokselet cihazında petrol eteri ekstraksiyonu ile saptanmıștır.

Çizelge 2. Deneme toprağının bazı kimyasal ve fiziksel özellikleri

Table 2. Physical and chemical characteristics of the experimental soil

\begin{tabular}{|c|c|c|c|c|c|c|c|c|c|c|c|c|}
\hline \multirow[t]{2}{*}{$\mathrm{pH}$} & \multirow{2}{*}{$\begin{array}{c}\text { Toplam } \\
\text { Tuz } \\
(\%) \\
\end{array}$} & \multirow{2}{*}{$\begin{array}{c}\text { Organik } \\
\text { madde } \\
(\%)\end{array}$} & \multirow{2}{*}{$\begin{array}{c}\mathrm{CaCO}_{3} \\
(\%)\end{array}$} & \multicolumn{3}{|c|}{$\begin{array}{c}\text { Tekstür } \\
(\%)\end{array}$} & \multicolumn{6}{|c|}{$\begin{array}{l}\text { Alınabilir } \\
\left(\mathrm{mg} \mathrm{kg}^{-1}\right)\end{array}$} \\
\hline & & & & Kum & Silt & Kil & $P$ & K & $\mathrm{Zn}$ & $\mathrm{Fe}$ & $\mathrm{Mn}$ & $\mathrm{Cu}$ \\
\hline 8,04 & 0,03 & 0,94 & 8,5 & 44,7 & 17,1 & 38,2 & 7,54 & 152 & 0,30 & 2,64 & 4,13 & 1,05 \\
\hline
\end{tabular}


Her parselin tohumlarından 5 gram örnek alınmıș, bu örnekler önce öğütülüp sonra $105^{\circ} \mathrm{C}^{\prime} \mathrm{de}$ 2 saat süreyle kurutulmuștur. Kurutma ișleminden sonra eterle muamele edilerek yağı alınmıș ve tekrar $105^{\circ} \mathrm{C}$ de 2 saat bekletilerek tartılmıștır. Kuru numuneler arasındaki farklar oranlanarak \% yağ oranları bulunmuștur (Öğütçü, 1979). İstatistiki değerlendirme IBM SPSS 20 paket programı kullanılarak yapılmıștır. Ortalamaların karșılaștırımasında Duncan çoklu testi kullanılmıștır.

\section{BULGULAR VE TARTIȘMA}

Kanola bitkisine uygulanan Zn gübresinin verim, verim özellikleri ve yağ oranı üzerine etkisinin araștırıldığı çalıșmadan elde edilen verilere ait varyans analiz sonuçları ve incelenen özelliklere ait ortalama değerler Çizelge 3' de verilmiștir. Zn uygulamasının ilk yıl incelenen özelliklerde herhangi bir etkisi belirlenmemișken, ikinci yılda tohum verimi ve kapsülde tane sayısı özelliklerinde önemli bulunmuștur. Kanola çeșitleri, ilk yılda yan dal sayısı ve tohum verimi; ikinci yılda ise bitki boyu, her iki yılda bin tane ağırlığı bakımından farklıık göstermiștir. Uygulama x çeșit interaksiyonu her iki yılda da tohum verimi özelliğinde önemli olmuștur.
Yağ analizi sonuçlarının varyans analizi incelendiğinde ise hem Zn uygulamasının yağ oranı üzerine etkisi hem de çeșitler arasındaki fark önemsiz bulunmuștur.

Tohum verimini doğrudan etkileyen özelliklerin bașında gelen bitki boyu (Kolsarıcı ve Bașoğlu, 1984) vejetatif büyümenin de iyi bir göstergesidir. Kanolada bitki boyu üzerine genetik yapının etkisi oldukça fazladır (Bașalma, 1997), bununla birlikte çeșide, çevre koșullarına, ekim zamanına ve yapılan kültürel uygulamalara göre değișebilmektedir (Aytaç, 2007). İkinci yılda bitki boyu çeșitler arasında istatistiksel olarak farklı bulunmuștur. Samuray çeșidinin bitki boyu ikinci yılda 162,2 cm elde edilirken, Zorro çeșidinde 146,3 cm olarak belirlenmiștir.

Kanolada verimi etkileyen önemli verim özelliklerinden biri de ana sapa bağlı yan dal sayısıdır (Tunçtürk vd., 2005). Bitki bașına yan dal sayısı Zorro çeșidinde birinci yılda en yüksek (6,5 adet/bitki) bulunmuștur. Kanolada iyi bir verim için yan dal sayısının 6 olmasının ideal olduğu belirtilmiștir (Röbbelen ve Leitzke, 1974; Göksoy ve Turan, 1986). Wang vd., (2014) Zn gübrelemesinin

Cizelge 3. İncelenen özelliklerinin ortalama değerleri ve varyans analizi

Table 3. Mean values of the yield components and analysis of variance

\begin{tabular}{|c|c|c|c|c|c|c|c|c|c|c|}
\hline Yıl & Uyg. & Ceșit & $\begin{array}{l}\text { Bitki } \\
\text { Boyu }\end{array}$ & $\begin{array}{c}\text { Yan } \\
\text { Dal } \\
\text { Sayısı }\end{array}$ & $\begin{array}{c}\text { Bitkide } \\
\text { Kapsül } \\
\text { Sayısı }\end{array}$ & $\begin{array}{l}\text { Kapsül } \\
\text { Uzunluğu }\end{array}$ & $\begin{array}{c}\text { Kapsülde } \\
\text { Tane } \\
\text { Sayısı }\end{array}$ & $\begin{array}{l}\text { Bin } \\
\text { Tane } \\
\text { Ağ. }\end{array}$ & Verim & $\begin{array}{l}\text { Yağ } \\
\text { Oranı }\end{array}$ \\
\hline \multirow{11}{*}{ I.YIL } & \multirow{2}{*}{$\mathrm{Zn}(-)$} & Samuray & 134,7 & 5,6 & 117,9 & 7,0 & 24,3 & 4,5 & $292,2 \mathrm{c}$ & 41,0 \\
\hline & & Zorro & 131,6 & 6,3 & 113,7 & 7,3 & 25,7 & 3,8 & $320,0 a$ & 40,6 \\
\hline & \multirow{4}{*}{$\mathrm{Zn}(+)$} & Ort. & 133,2 & 6,0 & 115,8 & 7,2 & 25,1 & 4,2 & 306,1 & 40,9 \\
\hline & & Samuray & 137,7 & 5,7 & 111,3 & 7,0 & 25,7 & 4,6 & $308,2 b$ & 42,5 \\
\hline & & Zorro & 140,4 & 6,5 & 107,3 & 7,0 & 24,3 & 3,4 & $307,7 b$ & 43,5 \\
\hline & & Ort. & 139,1 & 6,2 & 109,4 & 7,1 & 25,0 & 4,0 & 308,0 & 43,1 \\
\hline & \multirow[t]{5}{*}{ Ort } & Samuray & 136,3 & $5,7 b$ & 114,6 & 7,0 & 25,0 & $4,6 a$ & $300,3 b$ & 41,8 \\
\hline & & Zorro & 136,1 & 6,5a & 110,6 & 7,2 & 25,0 & $3,7 b$ & 313,9а & 42,1 \\
\hline & & Uygulama (U) & ns & ns & ns & ns & ns & ns & ns & ns \\
\hline & & Çeșit (Ç) & ns & * & ns & ns & ns & ** & ** & ns \\
\hline & & $U \times C$ & ns & ns & ns & ns & ns & ns & $\star *$ & ns \\
\hline \multirow{11}{*}{ II.YIL } & \multirow{3}{*}{$\mathrm{Zn}(-)$} & Samuray & 161,0 & 6,5 & 117,3 & 5,7 & 22,8 & 4,1 & $343,4 c$ & \\
\hline & & Zorro & 149,2 & 6,3 & 112,9 & 5,8 & 24,5 & 3,5 & $346,6 \mathrm{~b}$ & \\
\hline & & Ort. & 155,2 & 6,4 & 115,2 & 5,8 & $23,7 b$ & 3,9 & $345,0 b$ & \\
\hline & \multirow{4}{*}{$\mathrm{Zn}(+)$} & Samuray & 163,2 & 6,3 & 121,1 & 6,1 & 26,2 & 4,3 & $369,8 a$ & \\
\hline & & Zorro & 143,2 & 6,8 & 125,7 & 6,0 & 26,5 & 3,7 & $343,7 c$ & \\
\hline & & Ort. & 153,3 & 6,6 & 123,5 & 6,1 & $26,4 a$ & 4,1 & $356,8 a$ & \\
\hline & & Samuray & $162,2 \mathrm{a}$ & 6,4 & 119,3 & 6,0 & 24,6 & 4,3а & 356,6 & \\
\hline & \multirow[t]{4}{*}{ Ort } & Zorro & $146,3 b$ & 6,6 & 119,4 & 6,0 & 25,5 & $3,6 \mathrm{~b}$ & 345,2 & \\
\hline & & Uygulama (U) & ns & ns & ns & ns & * & ns & * & \\
\hline & & Çeșit (Ç) & $* *$ & ns & ns & ns & ns & ** & ns & . \\
\hline & & $\cup \times c$ & ns & ns & ns & ns & ns & ns & * & \\
\hline
\end{tabular}

+ns: önemsiz, *: $p<0,05 * *$ : $p<0,01$ (Harfler farklı grupları göstermektedir.) 
kanolanın bitki boyu ve yan dal sayısını arttırdığını tespit etmiștir. Ancak bu çalıșmanın sonuçları ile uyum göstermemektedir. Bu da genotip, toprak ve iklim özelliklerinden kaynaklanmıș olabilir.

Kapsülde tane sayısında ikinci yılda Zn uygulamaları arasında istatistiki anlamda fark çıkmıștır. İkinci yılda her iki çeșit Zn uygulaması ile kapsülde tane sayısını arttırmıștır (26,4 adet) (Çizelge 3). Çeșitlerin bin tane ağırlığı her iki yılda da istatistiki olarak $(p<0,01)$ önemli bulunmuștur. Bin tane ağırlığında en yüksek değer her iki yılda da Samuray çeșidinin Zn uygulamalarından (ilk yıl 4,6 g ve ikinci yıl 4,3 g) elde edilmiștir. Hedayatpour vd., (2014) ve Wang vd., (2014) kanola bitkisine Zn uygulamasıyla kapsülde tane sayısı ve bin tane ağırlığının arttığını bildirmiștir. Kanolanın bin tane ağırlığı çevre koșullarından en çok etkilenen özelliklerden birisidir (Schuster, 1970; Kondra, 1977; Schuster ve Taghizadeh, 1980).

Tohum verimine bitki boyu, yan dal sayısı, bitkide kapsül sayısı, kapsülde tohum sayısı, kapsül uzunluğu, bin tane ağırlığı gibi özelliklerinin önemli katkıları olduğu bildirilmektedir (Campbell ve Kondra, 1978; Chay ve Thurling, 1989; Kolsarıcı vd., 1993). Diğer bitkilerde olduğu gibi kanolada da tohum verimi, verimi olușturan özelliklerden, çevre șartlarından ve değișik tarımsal uygulamalardan etkilenmektedir. Tohum veriminde ikinci yıl Zn uygulaması, her iki yılda da uygulama x çeșit interaksiyonu istatistiki olarak önemli bulunmuștur. Denemenin ikinci yılında Samuray çeșidinin tohum verimi Zn uygulamasıyla birlikte istatistiksel olarak önemli düzeyde değișmiș ve artıș göstermiștir (+Zn 369,8 ve -Zn 343,4 kg da-1) (Çizelge 3). Gerek bitki türleri gerekse aynı türün içindeki çeșitler Zn gübrelemesine karșı farklı tepkiler gösterdiği bazı araștırmacılar tarafından belirlenmiștir (Çakmak vd., 1996; Torun vd., 2000). Bu araștırmada en yüksek ortalama tohum verimi değerleri ikinci yıldan elde edilmiștir. Özellikle ikinci yılda vejetatif gelișim açısından önemli olan Eylül ve Ekim aylarından elde edilen toplam yağıș miktarları birinci yılda elde edilenden fazla olmuștur. Ayrıca tohum olgunlașma dönemi bakımından önem tașıyan Mayıs ve Haziran aylarından elde edilen toplam yağıș miktarları da aynı șekilde ikinci yılda birinci yıla göre daha yüksektir. İkinci yılda elde edilen toplam yağıș miktarının daha yüksek olması kapsülde tohum sayısını, bu da tohum verimini arttırmıș olabilir. Zn uygulamasının Samuray çeșidinde ikinci yılda tohum verimini arttırdığı buna karșılık Zorro çeșidinde önemli bir etki göstermediği belirlenmiștir. Bu sonuç Zn uygulamasının çeșitlere ve çevre koșullarına göre farklı etki gösterdiğini ortaya koymakta ve uygulama x çeșit interaksiyonuna bağlı olan değișimin istatistiki olarak önemli olmasını açıklamaktadır. Çinkonun topraktan ve yapraktan uygulamasının kanolanın verimine etkisini araștıran bazı araștırmacılar da (Omidian vd., 2012; Rezaei vd., 2013; Hedayatpour vd., 2014; Wang vd., 2014), Zn uygulamasıyla birlikte verimin arttığını saptamıșlardır. Grewal vd., (1997) Brassica napus ve Brassica juncea türleri ile sera koșullarında yürüttükleri denemede, toprağa Zn uygulamasının kök gelișimini, bitki çıkıșlarını, tohum miktarını, tohum ağırlığını ve tohum verimini arttırdığını bildirmișlerdir. Bu araștırmanın sonuçlarına göre Zn uygulamasının Samuray çeșidinde her iki yılda da tohum verimini arttırdığı ve bu artıșın artan tane sayısına bağlı olarak gerçekleștiği görülmektedir. Uygulama x çeșit interaksiyonunun istatistiki olarak önemli olmasından da görüldüğü üzere çeșitler Zn uygulamalarından farklı etkilenmiștir. Zn uygulamasına en iyi tepki veren çeșit Samuray çeșidi olmuș, veriler yıllara göre değișiklik göstermiștir.

Tarla koșullarında uygulanan Zn'nun bitkinin büyüme dönemi süresince bitkiye yarayıșlılığı ve bitki tarafından alınabilmesi uygulanan gübre miktarından, yetiștirildiği toprağın özelliklerinden ve yağıș dağılımından etkilenmektedir (Al-Doori, 20014). Denemenin birinci yılında, yapılan yağ analizi sonucuna göre ise uygulamalar ve çeșitler arasında istatistiki olarak fark bulunmamıștır (Çizelge 3). Ayçiçeğinde artan dozlarda (0, 1, 2, 3, 6 kg da1) Zn'nun uygulandığı bir çalıșmada, yağ içeriğinin dekara $1 \mathrm{~kg} \mathrm{da}^{-1} \mathrm{Zn}$ uygulanmasıyla Zn uygulanmayan koșullara göre bir artıș olduğu, dekara 1 kg'dan sonra ise azalıș gösterdiği bildirilmiștir (Mirzapour ve Khoshgoftar, 2006). Buna göre değerlendirildiğinde; bizim çalıșmamızda uygulanan $3 \mathrm{~kg} \mathrm{da}^{-1} \mathrm{Zn}$ dozunun yağı azaltmasa da önemli düzeyde bir artıșa yol açmamasının bir nedeni etkili doz olmama olasılı̆ı olabilir. Ayrıca Hu vd., (1994)'nin kanolada Zn ve P'un etkisini görmek amacıyla yürüttükleri bir çalıșmada toprağa artan oranlarda uygulanan Zn'nun tohum verimini \% 18 arttırdığı bulunmuștur.

Toprağa uygulanan Zn' nun etkisi sulanan veya yağıșlı koșullarda daha belirgin ve etkili olmaktadır (Ekiz vd., 1998; Hong ve Ji-Yun, 2007). İkinci yılda tohum sayısı haricinde diğer verim özelliklerinde ve yağ oranlarında topraktan Zn gübre uygulaması 
yapılmasına rağmen istatistiki anlamda önemli bir artıș görülmemesi, her iki yılda alınan yağıș miktarının uygulanan Zn'nun topraktaki yarayıșıııı̆ını sınırlandırdığını düșündürmektedir. Bu sebepten dolayı, özellikle çıkıș sulaması dıșında bitkinin vejetasyon süresi boyunca hiçbir sulamanın yapılmadığı düșünülürse sulamanın özellikle topraktaki Zn yarayıșlıı̆ı̆ını arttırmada büyük önem tașıdığı görülmektedir. Nitekim Zou vd., (2012)'nin yapmıș oldukları farkı lokasyonlardaki çalıșmalarda sulama yapilmayan lokasyonlarda topraktan uygulanan Zn'nun kontrole göre tane verimini arttırmada etkisinin sınırlı olduğu görülmüștür. Bu çalıșmada vejetasyon dönemi boyunca herhangi bir sulamanın yapılmamıș olması Zn'nun topraktaki yarayıșlıı̆ının yeterli düzeyde ortaya çıkmamasına, verim özellikleri üzerine (istatistiki sonuçlardan da görüldüğü üzere) etkisinin görülmemesine sebep olmuș olabilir. Sadece \% 5 düzeyinde de olsa ve sadece ikinci yılda kapsülde tohum sayısı ve tohum verimi, Zn uygulamasından etkilenmiș olup, buradaki artıșın da birinci yıla göre biraz daha yüksek (54 mm daha yüksek) olan toplam yağıșla ilișkili olduğu ifade edilebilir.

İklim koșulları, farklı genotipler de çinko uygulamasına bitkinin tepkisini sınırlandırmaktadır (Graham vd., 1999; Ekiz vd., 1998). Bitki yetișme dönemi boyunca Zn'nun uygulanma zamanı tohum verimi ve yağ içeriği üzerine etkili olabilmektedir. Nitekim Babaeian vd., (2011) Zn'yu çiçeklenme zamanında yapraktan uygulamıșlar ve tohum verimi ve yağ içeriğinin arttığını tespit etmișlerdir. Bizim çalıșmamızda Zn dozunun yanı sıra Zn uygulama yöntemi de, tohum verimi ve yağ miktarının fazla bir artıș göstermemesinin bir nedeni olabilir. Ileride yaprak, toprak, toprak+yaprak gibi farklı kombinasyonlarda bitkinin kritik gelișim sürecinde Zn uygulaması yapılarak bu konuda daha net açıklayıcı sonuçlar elde edilebilir. Bunun yanı sıra, literatürlerde bildirilen görüșlere göre (Coleman, 1992; Gitte vd., 2005; Mirzapour ve Khoshgoftar, 2006) Zn'nun noksan olduğu koșullarda Zn gübresi uygulanması sonucunda bitki tarafından alınan Zn öncelikle tohumdaki yağ aleyhine protein içeriğinde bir artıș sağlamaya dönük olarak kullanılmaktadır. Bizim çalıșmamızda da yağ miktarının fazla bir artıș göstermemesi, Zn uygulamasıyla bitki tarafından alınmıș olan Zn'nun öncelikle protein olușturmada kullanıımıș olmasından kaynaklanmıș olabilir. Açıklanan nedenler konunun bu faktörler gözetilerek daha ayrıntılı irdelenmesi gereğine ișaret etmektedir.

\section{SONUÇLAR}

Bu araștırmanın sonuçlarına göre; kanolaya topraktan Zn uygulaması kapsülde tane sayısını ve tohum veriminde artıș sağlamıștır. Yağ oranı ise çinko uygulamasından etkilenmemiștir. Kanolanın Zn gübrelemesi yapılırken iklim özellikleri, Zn uygulama dozları ve Zn uygulama yöntemleri de göz önünde bulundurulmalı ve çalıșmalarda genotiplerin Zn etkinlik değerleri de tespit edilmelidir. Zn noksanlığının yaygın olduğu alanlardaki kanola yetiștiriciliğinde Zn gübrelemesi yapılamayan koșullar için tohum ve yağ verimi yanında, Zn etkinliği yüksek olan genotiplerin; Zn gübrelemesi imkanı olan koșullarda ise $\mathrm{Zn}$ uygulamalarına daha iyi cevap veren genotiplerin tespit edilmesine yönelik tarla çalıșmalarının gerçekleștirilmesi önemli olacaktır.

\section{KAYNAKLAR}

Al-Doori SAM (2014). Effect of different levels and timing of zinc foliar application on growth, yield and quality of sunflower genotypes (Helianthus annuus L., Compositae). College of Basic Education Researchers Journal, 13(1): 907-922.

Alloway B J (2008). Zinc in soils and crop nutrition. 2nd ed. Int. Zinc Assoc., Brussels, Belgium.

Anonim (2007). Meteoroloji İșleri Genel Müdürlüğü, Eskișehir.

Anonim (2014). FAOSTAT, Agricultural Database. Erșișim: http:// www.fao.org.

Aytaç Z (2007). Bazı kıșlık kanola (Brassica napus ssp.oleifera L.) çeșitlerinin tarımsal özellikleri ve Eskișehir koșullarına adaptasyonu, Doktora Tezi, Eskișehir Osmangazi Üniversitesi Fen Bilimleri Enstitüsü, Eskișehir. $112 \mathrm{~s}$.

Aytaç Z, Kınacı G (2007). Orta Anadolu koșullarında kanola çeșitlerinin verim ve verim öğeleri üzerine azotlu gübrelerin etkileri. VII. Türkiye Tarla Bitkileri Kongresi, 25-27 Haziran 2007, Erzurum.

Babaeian M, Tavassoli A, Ghanbari A, Esmaeilian Y and Fahimifard M (2011). Effects of foliar micronutrient application on osmotic adjustments, grain yield and yield components in sunflower (Alstar cultivar) under water stress at three stages. African Journal of Agricultural Research. 6 (5): 1204-1 208.

Bașalma D (1997). Adaptation of winter type Germany origionated rapeseed (Brassica napus ssp. oleifera L.) cultivars under Ankara Conditions. Tarım Bilimleri Dergisi. 3(3): 57-62.

Bașalma D (1999). N'lu gübrelemenin kolzanın verim ve verim öğelerine etkisi. Tarla Bitkileri Araștırma Enstitüsü Dergisi, 8: $1-2$.

Bașalma D (2004). Kıșlık kanola (Brassica napus ssp.oleifera L.) çeșitlerinin Ankara koșullarında verim ve verim öğeleri yönünden karșılaștırılması. Tarım Bilimleri Dergisi, 10 (2): 21 1-217.

Bașalma D, Kolsarıcı Ö (1998). Determination of yield components of winter type french originated rapeseed (Brassica napus ssp. oleifera L.) cultivars under Ankara conditions. Deutsch-Türkische Agrarforschung Symposium, Antalya. 
Bouyoucos G J (1955). A recalibration of the hydrometer method for making mechanical analysis of the soils, Agronomy Journal 4 (9): 434.

Caarson P L (1980). Recommended potassium test. Pç 2021 IN: Recommended Chemical Soil Test Procedures for The North Central Region. Reu. Ed. North Central Regional Publication no.221. North Dakota Agric. Exp Stn. North Dakota State University Fargo. USA.

Coleman J E (1992). Zinc proteins enzymes, storage proteins, transcription factors and replicate proteins. Annual Review of Biochemistry, 61: 897-946.

Çakmak I, Yılmaz I, Kalaycı M, Ekiz H, Torun B, Erenoğlu B, Braun H J (1996). Zinc deficiency as critical problem in wheat production in Central Anatolia. Plant and Soil, 180: 165- 172.

Çakmak I, Kalaycı M, Ekiz H, Braun H J, Yılmaz A (1999). Zinc deficiency as an actual problem in plant and human nutrition in Turkey: A NATO-Science for Stability Project. Field Crops Research 60: 175-188.

Çakmak I, Yılmaz I, Kalaycı M, Ekiz H, Torun B, Erenoğlu B, Braun H J (1996). Zinc deficiency as critical problem in wheat production in Central Anatolia. Plant and Soil, 180: 165- 172.

Campbell D C, Kondra ZP (1978). Relationships among growth patterns, yield components and yield of rapeseed. Canadian J.of Plant Sci. 58: 87-93.

Chay P, Thurling N (1989). Identification of genes controlling pod length in spring rapeseed, Brassica napus L., and their utilization for yield improvement. Plant Breeding 103 $54-62$.

Downey R K, Röbbelen G (1989). Brassica spacies. In: G Röbbelen, RK. Downey and A Ashri McGraw (Eds.). Oil crops of the world. Hill Publ. Co. New York, USA. Chapter 16. Pp. 63-86.

Ekiz H, Bağcı S A, Kıral A S, Eker S, Gültekin I, Alkan A, Cakmak I (1998). Effects of zinc fertilization and irrigation on grain yield and zinc concentration of various cereals grown in zinc-deficient calcareous soils. Journal of Plant Nutrition 21 (10): 2245-2256.

Gitte A N, Patil S R, Tike M A (2005). Influence of zinc and zinc biochemical and yield characteristics of sunflower. Journal of Plant Physiology. 10 (4): 431-438.

Göksoy A T, Turan Z M (1986). Bazı yağık kolza (Brassica napus ssp. oleifera L) çeșitlerinde verim ve kaliteye ilișkin karakterler üzerinde araștırmalar. Uludağ Üniversitesi Ziraat Fakültesi Dergisi. 5: 76-83.

Graham R D, Ascher J S, Hynes S C (1992). Selection of zincefficient cereal genotypes for soils of low zinc status. Plant Soil 146:241-250

Graham R D, Senadhira D, Beebe S, Iglesias C, Monast erio I (1999). Breeding for micronutrient density in edible portions of staple food crops: conventional approa ches. Field Crop Res 60:57-80.

Grewal H S, Zhonggu L, Graham R D (1997). Influence of subsoil zinc on dry matter production, seed yield and distribution of zinc in oilseed rape genotypes differing in zinc efficiency. Plant and Soil 192: 181-189.

Grewal H S, Stangoulis J C R, Potter T D, Graham R D (1997a). Zinc efficiency of oilseed rape (Brassica napus and $B$. juncea) genotypes. Plant and Soil. 191: 123-132.
Grewal H S, Zhonggu L, Graham R D (1997b). Influence of subsoil zinc on dry matter production, seed yield and distribution of zinc in oilseed rape genotypes differing in zinc efficiency. Plant and Soil 192: 181-189.

Hedayatpour $R$, Dehnavi M M, Khademhamzeh $H$, Morshedi S M (2014). Effect of foliar application of zinc and iron on yield and quality of canola (Brassica napus Cv. Talaya) in Zarghan region. Fars. Journal of Oil Plant Production, 1(1): 33-42.

Hong W and Ji-yun J (2007). Effects of zinc deficiency and drought on plant growth and metabolism of reactive oxygen species in maize (Zea mays L.). Agricultural Sciences in China, 6(8): 988-995.

Hu D J, Bell R W, Xie Z C (1996). Zinc and phosphorus responses in transplanted oilseed rape (Brassica napus). Soil Science and Plant Nutrition. 42 (2): 333-344.

Huang L, Hu D, Bell R W (1995). Diagnosis of zincdeficiency in canola by plant analysis. Communications in Soil Science and Plant Analysis. 26: 17-18.

Kırıcı S, Özgüven M (1995). Çukurova bölgesine verim, kalite ve erkencilik bakımından uyabilecek kolza çeșitlerinin saptanması. C.Ü. Ziraat Fak. Dergisi, 10 (3): 105-120.

Kolsarıcı Ö ve Bașoğlu F (1984). Yağ kalitesi ve yağ oranı yüksek kıșlık kolza çeșit ve hatlarının verim komponentleri yönünden karșılaștırıması, Ankara Üniversitesi Ziraat Fakültesi Yıllığı, 34: 66-76.

Kolsarıcı Ö, Er C, Tarman D (1985). Islah edilmiș kıșlık kanola çeșitlerinde verim komponentlerinin karșılaștırılması. Ankara Ünv. Zir. Fak. Yıllığı 86, Cilt 35, Ankara, 61-74.

Kolsarıcı Ö, Aytekin Ș, Vurdu N, Gönenç B (1993). Yabancı kökenli kıșlık kolza çeșitlerinde verim komponentlerinin dağılımı. Lisans tezi. Ankara Üniversitesi, Ziraat Fakültesi Tarla Bitkileri Anabilim Dalı, Ankara, $19 \mathrm{~s}$.

Kolsarıcı Ö (2009). Tarla Bitkileri. Ankara Üniversitesi Ziraat Fakültesi Yayınları, No: 1569, Ders Kitabı: 521, sayfa:410, Ankara.

Kolsarıcı Ö, Kaya M D, Göksoy A T, Arıoğlu H, Kulan E G, Day S. (2015). Yağlı tohum üretiminde yeni arayıșlar, TMMOB Ziraat Mühendisleri Odası, Türkiye Ziraat Mühendisliği VIII Teknik Kongresi, 413-414

Kondra Z P (1977). Effects of planted seed size and seeding rate on rapeseed. Canadian J.of Plant Sci. 57: 277280.

Lindsay W L, Norvell W A (1978). Development of a DTPA soil Test for Zn, Fe, Mn and Cu. Soil Sci. Soc. Amer. Proc. 42:421-428.

Mirzapour M and Khoshgoftar A (2006). Zinc application effect on yield and seed oil content of sunflower grown on a saline calcareous soil. Journal Plant Nutrition 29(10): 1719 1727.

Nriagu J (2010). Zinc deficiency in human health. Encyclopedia of Environmental Health, pp. 789-800

Olsen S R, Dean LA (1965). Phosphorus. Editor C.A. Black. Methods of Soil Analysis. Part 2. American Society of Agronomy. Inc. Publisher Madison, Wilconsin, U.S.A. 10351049. 
Omidian A, Siadat S A, Nasari R Maradi M (2012). Effect of foliar application of zinc suphate on grain yield, oil and protein content in four rapeseed (Brassica napus L.) cultivars. Iranian Journal of Crop Sciences, 14(1): 16-28.

Öğütcü Z (1979). Orta Anadolu koșullarında kıșlık yetiștirilen kanola (Brassica napus ssp. oleifera L) çeșitlerinin verim ve kaliteye ilișkin karakterleri. Ankara Üniversitesi Ziraat Fakültesi Yayınları, 717, Bilimsel Araștırma ve İncelemeler 417, Ankara. s.75.

Öztürk Ö, Akınerdem F (2000). Bazı kıșlık kanola çeșitlerinde farklı ekim zamanı ve sıra arası uygulamaların verim ve verim unsurları ve kalite üzerine etkileri. S.Ü. Ziraat Fakültesi Fen Bilimleri Enstitüsü Doktora Tezi, Konya. $147 \mathrm{~s}$.

Rezaei E, Dadnia M R, Allahdad S, Zare S (2013). Evaluation of zinc and potassium effects on drought stress resistance, yield and yield components in rapeseed. International Journal of Agriculture and Crop Sciences.

Richards L A (1954). Diagnosis and improvement of saline and alkali soils. US Salinity Lab. United States Department of Agriculture Handbook 60:94. California, USA.

Röbbelen G, Leitzke B (1974). Stand und probleme der züchtung erucaseurearmer rapssorten in der Bundesrepublik Deutschland. Proc. 4.Int. Rapskongress, 4-8 Juni 1974, Giessen, 63-71.

Tan A S (2009). Bazı kolza (kanola) çeșitlerinin Menemen koșullarında verim potansiyelleri. Ege Tarımsal Araștırma Enstitüsü Dergisi, Anadolu, J. Of AARI., 19 (2): 1-32.
Torun B, Bozbay G, Gültekin I, Braun H J, Ekiz E, Cakmak i (2000). Differences in shoot growth and zinc concentration of 164 bread wheat genotypes in a zinc-deficient calcareous soil. J of Plant Nutrition 23 (9): 1251-1265.

Tunçtürk M, Yılmaz İ, Erman M, Tunçtürk R (2005). Yazlık kolza (Brassica napus ssp. oleifera L.) çeșitlerinin Van ekolojik koșullarında verim ve verim özellikleri yönünden karșılaștırılması. Ankara Üniversitesi Ziraat Fakültesi Tarım Bilimleri Dergisi, 11 (1): 75-85.

Walkley A, Black $L A$ (1934). An examination of the Degtjareff method for determining soil organic metter and a proposed madification of the chramic acid titration method. Soil science, 37: 29-38.

Wang Y, Li J, Gao X, Li X, Ren T, Cong R, Lu J (2014). Winter oilseed rape productivity and nutritional quality responses to zinc fertilization. Agronomy Journal, 106 (4): 1349-1357.

Schuster W (1970). Deviation in fat content of different oil plants. I.Winter rape and sunflower. Field Crops Abstr. 23 (1): 85.

Schuster W, Taghizadeh A (1980). Über leistungen und qualität von sommerraps von sommerraps auf ökologisch stark differenzierten standorten. Bayer. Landwirtsch. Jb, 57: 221 237.

Zou C Q, Zhang Y O Rashid A, Ram H, Savasli E, Arisoy R $Z$, Hassan M (2012). Biofortification of wheat with zinc through zinc fertilization in seven countries. Plant and soil, 361(1-2): 119-130. 